\title{
A Review of 3D Printing in Construction and its Impact on the Labor Market
}

\author{
Md. Aslam Hossain $1, * \mathbb{C}$, Altynay Zhumabekova ${ }^{1}$, Suvash Chandra Paul ${ }^{2} \mathbb{C}$ and \\ Jong Ryeol Kim ${ }^{1, *(D)}$ \\ 1 Department of Civil and Environmental Engineering, Nazarbayev University, Nur-Sultan 010000, \\ Kazakhstan; altynay.zhumabekova@nu.edu.kz \\ 2 Department of Civil Engineering, International University of Business Agriculture and Technology, \\ Dhaka 1230, Bangladesh; suvashpl@iubat.edu \\ * Correspondence: md.hossain@nu.edu.kz (M.A.H.); jong.kim@nu.edu.kz (J.R.K.); \\ Tel.: +7-7172-709123 (M.A.H.); +7-7172-70-9136 (J.R.K.)
}

Received: 7 September 2020; Accepted: 25 September 2020; Published: 15 October 2020

\begin{abstract}
Construction industry is very labor-intensive and one of the major sources of employment in the world. The industry is experiencing low productivity with minimum technological innovations for decades. In recent times, various automation technologies including 3D printing have received increasing interests in construction. 3D printing in construction is found to be very promising to automate the construction processes and have the potential of saving laborious work, material waste, construction time, risky operation for humans, etc. There has been a comprehensive body of research conducted to understand the recent advances, future prospects and challenges of large-scale adoption of $3 \mathrm{D}$ printing in construction projects. Being one the labor-intensive industries, this study also investigates the possible impact on the labor market with increasing adoption of $3 \mathrm{D}$ printing in construction. It is found that 3D printing can reduce significant number of labors which can solve the labor shortage problem, especially for the countries where construction is heavily dependent on immigrant workers. In contrast, 3D printing might not be favorable for the countries where construction is one of the main workforces and labor is less expensive. Moreover, 3D construction printing will also require people with special skills related to this new technology.
\end{abstract}

Keywords: 3D construction printing; additive manufacturing; workforce; construction labor; immigrant workers

\section{Introduction}

The construction industry is among the main industries that contributes to countries' economic development, with a 9\% GDP (gross domestic product) share and about 7 8.5\% of the total employment around the world [1-3]. Total worldwide spending in construction was USD 11.4 trillion in 2018 and is expected to increase to USD 14 trillion by 2025 [4]. Being huge economic contributors, the industry is yet characterized by low productivity with low technological advances, minimum automation and robotic usage, etc. Traditionally, construction projects are highly fragmented and unique in nature which impede the automation process of this industry. Moreover, as mentioned in [5], the construction industry receives relatively low investment in technology which further hampers productivity growth. There is a strong link between the level of digitization in a sector and its productivity improvement. The construction industry in the U.S. has invested only $1.5 \%$ of value added on technology which is much lower than the manufacturing industry $(3.3 \%)$ and the overall average in the economy of $3.6 \%$. Various analyses portray that the productivity in the construction industry has remained almost the same over the last few decades, whereas the productivity in manufacturing has nearly doubled $[6,7]$. 
Recent studies depict that the construction industry is gradually embedding automated systems and robotic usages, mostly in the research and development phase with very limited practical applications [8-11]. Virtual reality, augmented reality, mixed reality, drones, robotic arms, lesser scanning/photogrammetry, 3D printing (3DP), etc., are the many forms of automation being researched and used in construction. Nevertheless, most of these automated technologies are particularly used for some specific projects. Considering the unique nature of construction projects, these technologies are not readily applicable or repeatable to multiple construction projects unlike manufacturing productions [11]. This warrants further research to adopt the automated technologies on a large scale.

3D printing, also known as additive manufacturing, is an automated process that produces complex shape geometries from a 3D model (computer-aided design (CAD) model) on a layer-by-layer basis, through a series of cross-sectional slices. It has the potential to reduce material waste, decrease labor cost and fast production [12]. Its use in the various fields of manufacturing industries such as automobile, aerospace, medical, etc., has continued to grow for decades [12-14]. Building and construction industries are the last to adopt the 3DP technology considering the fact that building construction is incredibly different from industrial factories which can produce multiple copies of a single product [14-16]. Using the additive technology, printing of concrete for houses and villas has better prospect than construction of large structures $[16,17]$. This is because 3D concrete/construction printing (3DCP) possess various shortcomings such as limited capacity of 3D printer for high-rise buildings, insufficient printing materials (especially for load-bearing components), low level of customization, complexity involved in the information processing from design to tangible object, etc. $[16,18]$. Apart from printing buildings, 3DCP has been successfully explored in printing pedestrian bridges, in situ repair works for which access is difficult and dangerous for humans, quick building of disaster relief shelters, military bunkers, constructing metal frames, structural and non-structural elements with complex geometries, printing molds for load bearing components, reproduction of historical building components, etc. [10,16,18-20].

3DP is the new technology in the construction sector; there are strong arguments on the benefits offered and challenges to overcome by this technology. Among the numerous prospects of 3DCP as found in the literature, cheaper construction, reduced material use, improved safety, less reliance on human resources, better branding and market share, durable and sustainable construction, etc., are widely discussed $[12,13,21,22]$. One of the main advantages of 3DCP is found to be savings in labor requirements $[14,17,23]$. Even though construction works are historically very labor intensive, the impact of the labor market due to the use of 3DP in construction has not been extensively investigated.

Labor plays an important role in the construction industry. As mentioned earlier, according to the International Labor Organization [3], the construction industry produces about $8.4 \%$ employment in the world. In the contrary, the industry is struggling to improve the productivity for decades since construction works are highly dependent on human workforces with little use of technology and industrialization [24,25]. This workforces account at least $25 \%$ of the total project cost [26]. Often unskilled labor and/or shortage of labor also hamper the construction progress $[8,27]$. Surely, increasing use of technologies including the 3DCP would minimize the reliance on human resources with the potential to increase productivity and improve occupational safety and health of the workers by reducing risky works are to be done with innovative technologies [8]. Therefore, a large-scale adoption of 3DP in construction could be beneficial for the construction industry with a possibility of significant job cuts for many people around the world. This is an ambivalent situation that should be explored in more detail.

Accordingly, this study investigates the impact of labor market due to the use of 3DP in construction. Through a wider search of the literature and case study analyses, the study aims to understand how 3DCP would replace conventional construction activities in terms of labor requirements, labor cost, productivity improvement, occupational safety and health, and effects on job market. The study would be particularly important for the countries where construction is one of the major workforces, as well 
as for the places where there is a shortage of skilled construction laborers and workers and are highly dependent on migrated workers.

\section{Use of Automation in Construction}

Historically, the construction industry is labor intensive with little use of automation [24]. The degree of automation in construction is significantly lower than other industries, which eventually hampers productivity and causes risky working conditions $[10,11,28]$. The effect of introducing semi-automated construction equipment is evident as the technological revolutions in construction. For instance, hydraulic excavators and bulldozers carry out the earthwork tasks much faster and easier than it appeared when these jobs were done by conventional cable- or chain-operated shovels. The first machinery of this kind was invented back in 1882 by Sir W. G Armstrong \& Company in England [29]. The steam cylinder provided a dipper with a wide range of motion, allowing it to crowd horizontally and maneuver boulders. When machinery for drilling and inserting piles were invented and implemented, it changed the whole situation for underground engineering, performing the work faster and more accurately, eliminating all possible workmanship errors. Optimization of work with concrete happened when conveyors and pumps were developed in 1957 by Friedrich Wilhelm Schwing's company Schwig GmbH [30]. While cranes could only achieve a $12 \mathrm{~m}^{3}$ per hour speed of placing liquid concrete, a pump went up to $50 \mathrm{~m}^{3}$ per hour. It immediately reduced the number of workers needed for concrete placing, since the concrete could be accurately placed from the hose with minimum effort and time.

Using various construction equipment, the performance of conventional construction has reached at a stagnation since 1970. Accordingly, initiation, advances, and growth of new technologies and strategies of construction automation has started, yet the approaches are still at their infancy [11]. With the rapid evolvement of computer software and hardware in the past few decades, major progress can be observed in robotic control, vision, sensing, mapping, localization, and planning modules that helps gradual increase in the use of automated technologies in construction [28]. Particularly, robots are being explored into a number of construction tasks such as brick laying, wall construction, plastering, façade installation, cleaning and inspection, prefabrication/modular buildings, beam assembly, etc. $[5,8,25]$.

Brehm [31] presented masonry wall construction by robots to increase the efficiency in masonry buildings with less people. However, it poses two major challenges. Firstly, the additional weight of robots must be supported by the floor slabs. Secondly, further research is needed to find a suitable and cost-effective rapid-hardening adhesive since mortar is not used in such masonry construction. Soto et al. [25] compared the performance of conventional and robotically fabricated concrete walls in terms of cost and time. It was found from the analyses that robotic fabrication was suitable over conventional construction for complex structures and there was no additional cost or time involved with the increasing complexity of wall geometry. However, for simple walls, conventional construction outperformed the robotic fabrication. Grigoryan and Semenova [32] proposed and experimented hinged robot with interchangeable nozzles so that automatic bricks laying can be done with a brick tong and glued with a cement mortar supply system through an extruder. The speed of work for such system needs to be further investigated. On the other hand, robotic beam assembly, automated construction and logistic system, and façade works including installation, cleaning and inspection for high-rise buildings were discussed in [8].

Bock [11] showed that the ability of robot systems has grown and is deployed in diverse field of construction and the built environment. As discussed, the numerous robotics/automation technologies include robot-oriented design, robotic industrialization, single task construction robots (STCRs), site automation, and ambient robotics. While robot-oriented design helps to develop an automated construction site, robotic industrialization facilitates large-scale prefabrication with robot supported industrial settings. On the other hand, STCRs are designed to perform a specific construction task in repetitive manner (e.g., plastering, painting, etc.). Site automation is a combination 
of prefabrication approaches and STCRs. Additionally, ambient robotics include service robot systems, STCR technologies, and other microsystems technology that become inherent elements of building components and building furniture. Nevertheless, all these robotic systems work in comparably unstructured environment and, thus, the full potential of robotic use has not been gained in construction like the manufacturing industry.

\section{Limitation of Robotic Usage in Construction}

Unlike any other product, each building is a prototype. This is because design of each building depends on location, functionality, materials used, and expenses. Therefore, it is difficult to standardize building projects. The positive side of the robot is that it is very flexible machine [33]. In case of wall construction, for example, the designer can experiment with robots in order to perfectly and effortlessly place every brick. However, for any little change (e.g., dimension), the robot should be programmed accordingly in terms of number of blocks, size, orientation, etc. Alternatively, artificial intelligence (AI)/machine learning should be incorporated for automatic control of the robot. Nevertheless, the degree of precision is extremely important in construction and balancing of human-robot integration is essential for successful adoption in construction [10,34]. Moreover, in case of masonry block construction by robots, inconsistency and interoperability issue can arise between block suppliers and laying of block by the constructor [31].

Implementation of automation and robotics technology are more demanding in high-rise buildings since the labor demand, complexity of construction and safety risks potentially increase with the height of buildings [8]. Additionally, the cost of machines increases as the dimensions of structural and non-structural component increase [32]. Large companies who are mainly the constructors of high-rise buildings can afford expensive investment on robots. Nevertheless, it is difficult to introduce robot technologies for the small and medium-sized companies who build small-scale and individualized buildings [31].

In recent time, another automated construction technology has received increasing attention which is 3D printing, alternatively know as additive manufacturing or digital fabrication (dfab). Using an automated machine (3D printer), the structure of a construction project is automatically printed on a layer-by-layer basis. Thus, this technology has huge potential to save laborious construction work and impact the construction labor market.

\section{3D Printed Construction}

Figure 1 shows the comparison between conventional construction processes with the 3DP construction. As can be seen, human resources are involved in various stages for conventional construction which is time consuming and expensive. Additionally, the final product comes with a significant amount of construction wastes. In the contrary, 3D printing is mostly automated that prints buildings from a computer-aided design (3D-CAD) with less involvement of human resources, and without any need of tooling, dies/formwork, and fixtures [14]. Thus, this method reduces many manual processes, labor requirements, and material waste.

The use of formworks in the conventional construction accounts for a substantial spending leading to higher labor, equipment and material costs as well as material waste [12,18,35]. Even for a simple geometrical configuration, the formwork accounts for $25 \%$ to $35 \%$ of the cost of the structural work including significant amount of execution time [36]. In addition to that, formwork labor productivity is further affected negatively by the complexity of the geometrical configuration and type of formwork used $[37,38]$. In contrast, productivity of 3DCP is not affected by the geometry of the construction architecture, as mentioned earlier.

According to a report by Markets and Markets, 3DCP has the potential to reduce construction waste by $30-60 \%$, labor cost up to $50-80 \%$ and construction time by $50-70 \%$ [39]. However, a more detailed quantification is needed to acquire a better understanding on the savings. Another study by Allouzi et al. [40] in Jordan depicted that 3D printing could reduce material cost by $65 \%$ compared to 
the conventional construction method, although other issues such as equipment cost, labor cost and construction time were not considered in the analysis. 3DCP is also environmental friendly compared to conventional construction as reported in [22].

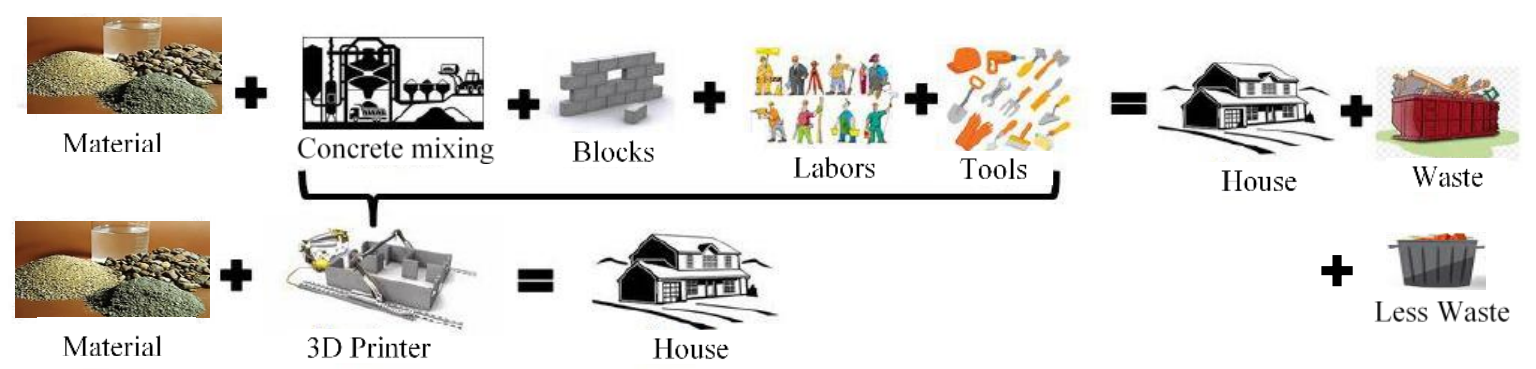

Figure 1. Conventional construction vs 3D printing construction process (derived from [41]).

Figure 1, however, is over-simplified and there exist many challenges in the 3DCP processes for which researchers are still working to make 3D-printed building a better choice over conventional construction. The key success of 3DCP mostly depends on the printing systems, properties of materials, as well as the skilled supervision of the work.

The printing systems mainly consist of automated technologies with big 3D printers to print large-size construction elements. A significant progress has been made on automated technologies and robotics in the construction domain, as discussed in Section 2. According to a report by Tractica [24], an increasing number of construction companies have started incorporating robots to solve the shortage of skilled labor and realize the benefits of better speed, efficiency, safety and profits. This growing interest in construction robots forecasts that more than 7000 construction robots are to be deployed between the periods of 2018 to 2025 with an increase in market revenue from USD 22.7 million in 2018 to USD 226.0 million in 2025, respectively [24]. A similar trend is also evident in 3DCP market. The market of 3DCP was about USD 130 million in 2017 and is expected to reach USD 314 million by 2023 [42].

For 3DCP, strict material quality control is required, which may be challenging especially in on site construction as opposed to off-site prefabrication in controlled atmospheres. The following section aims to summarize the types of materials used for 3DCP by researchers and their challenges for use in large scale construction.

\subsection{D Printable Materials and Challenges}

\subsubsection{Available Cement-Based Materials for 3D Printing}

The compositions of 3D printable cement-based materials are the same as conventional materials except for the proportions of binders and aggregates. The wet mix of 3D printable materials undergo various steps such as mixing, pumping, and deposition in a layer by layer; therefore, high-performance materials are required. In this regard, the proportion of binders and aggregates may vary from conventional materials. Various types of cement-based materials such as conventional mortar mix, geopolymer mortar, fiber mixed mortar, and nanoparticles mixed mortar have been successfully used in $3 \mathrm{DCP}$ by the researchers [43-45]. However, in the majority of the researches, sand is used as aggregate and limited research can be found where coarse aggregate was used [46]. Table 1 summarizes the mix compositions for 3D printable materials used by the researchers. It can be seen that a significantly higher content of binders is used. Nevertheless, the volumetric stability in these high binder content and fine aggregate-based 3D printable materials might be an issue for large scale construction. Therefore, more research is needed to develop materials with coarse aggregates. 


\subsubsection{Challenges for 3D Printable Materials in Large Scale Construction}

As mentioned earlier, the success of 3DCP depends on the properties of the material, more specifically, the fresh properties of 3D printable materials such as workability, viscosity, and green strength [47]. Typically, to avoid the deformation/settlement of bead layers (printing layers), no-slump yet pumpable material is required for 3DCP. Another option could be soft material, i.e., allowing some slump value but regain hardness as soon as the material is deposited through the nozzle head. The required viscosity profile of any acceptable 3D printable material is illustrated in Figure 2 [48]. It can be seen that before extrusion (i.e., before deposition through the nozzle head) material must have a higher viscosity, which then reduces during the printing period. This allows the material to be pumped from the mixing machine to the hose pipe and deposited through the nozzle head smoothly. Once deposited, the material must regain its previous viscosity so that the next layer can be deposited over it. In this way, the deformation of the bead layers can be controlled. This is challenging as it requires careful selection of material compositions, which may not be a major factor for conventional concrete. Most conventional concrete materials do not need to be pumped through the hose pipe and nozzle head. Although, in the existing concrete construction project, pumping concrete also known as the self-compacting concrete (SCC) is widely used because of its advantages in reducing time and no vibration required. However, the higher slump flow of SCC may not be acceptable for 3D printing.

Table 1. Summary of 3D printable materials used by the researchers.

\begin{tabular}{|c|c|c|c|c|}
\hline Authors & Binders $\left(\mathrm{kg} / \mathrm{m}^{3}\right)$ & Aggregates $\left(\mathrm{kg} / \mathrm{m}^{3}\right)$ & Water $\left(\mathrm{kg} / \mathrm{m}^{3}\right)$ & Others $\left(\mathrm{kg} / \mathrm{m}^{3}\right)$ \\
\hline Kruger et al. 2020 [43] & 827 & 1167 (max size $4.75 \mathrm{~mm}$ ) & 261 & SP: 12.2 \\
\hline Panda and Tan, 2018 [44] & 856 & 869 (max size $2 \mathrm{~mm})$ & 66 & Alkaline reagent: 356 \\
\hline $\begin{array}{l}\text { Nerella and Mechtcherine, } \\
\qquad 2019 \text { [45] }\end{array}$ & 780 & 1240 (max size $2 \mathrm{~mm})$ & 180 & SP: 10 \\
\hline Paul et al. 2018 [49] & 713 & 1212 (max size $2 \mathrm{~mm})$ & 285 & $\begin{array}{c}\text { Sodium } \\
\text { lignosulfonate } 7\end{array}$ \\
\hline Khalil et al. 2017 [50] & 683 & 850 (max size 2 mm) & 236 & SP: 1.76 \\
\hline Chen et al. 2019 [51] & 826 & $1242(\max$ size $2 \mathrm{~mm})$ & 248 & PCE: 17, VMA: 2 \\
\hline Ogura et al. 2018 [52] & \multicolumn{4}{|c|}{$\mathrm{W} / \mathrm{B}=0.22-0.24 ; \mathrm{S} / \mathrm{B}=0.2-1.2 ;$ Fiber $(\% . \mathrm{Vol}) 0.3-1.5$} \\
\hline Marchment et al. 2019 [53] & \multicolumn{4}{|c|}{$\mathrm{W} / \mathrm{B}=0.36 ; \mathrm{S} / \mathrm{B}=1.5$} \\
\hline
\end{tabular}

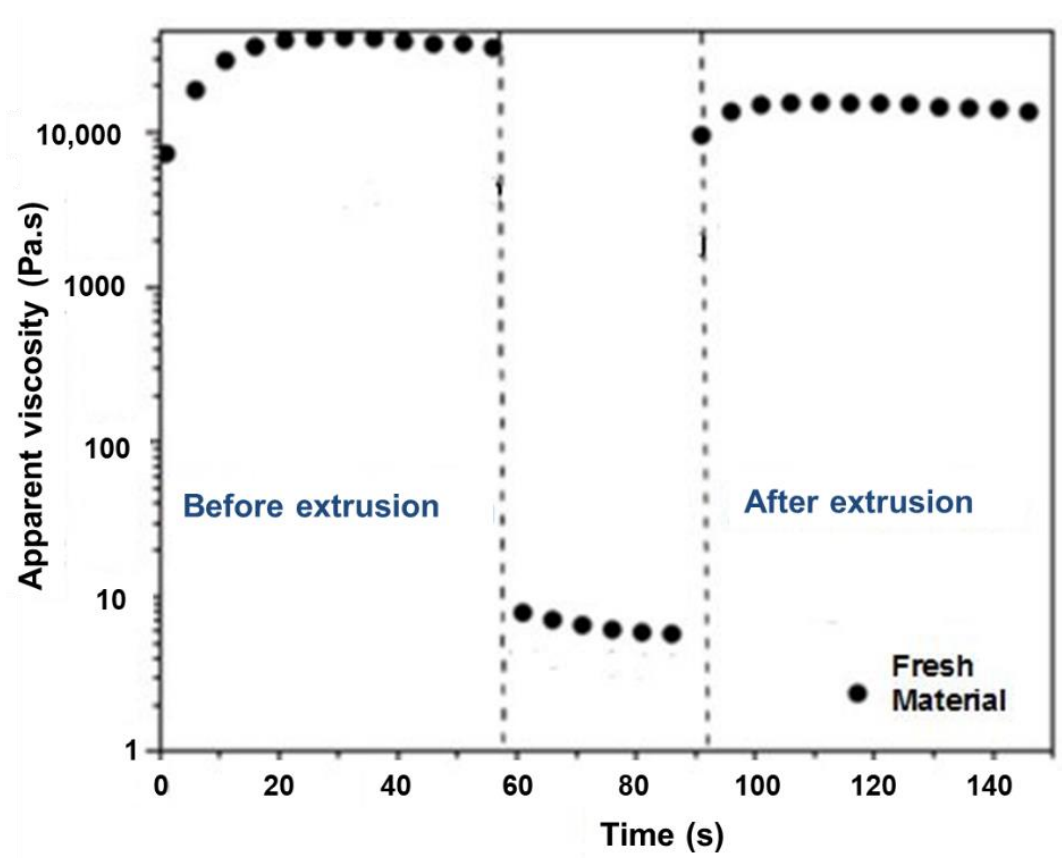

Figure 2. Required viscosity profile of fresh 3D printable material (retrieved from Panda et al. [48]). 
Other challenges for 3D printable materials can be the adhesion of bead layers, stand-off distance of the nozzle head, bead layer deformation or geometric conformity, nozzle direction changes on the layer density, and anisotropic behaviour of printable objects [54-57]. All these factors can significantly influence the performance of the 3D-printed objects. Atmospheric conditions and skilled supervision also play an important role in the success of 3DCP. Since the properties of materials are related to the atmospheric condition, therefore controlled environment is preferable for the high performance 3D printable materials. Similarly, for 3DCP, special machines and computer software are used which require skilled persons to operate successfully. These factors are the major challenges for this new technology and need to be given due consideration before the adoption in the construction sector.

\subsection{Other Challenges with $3 D C P$}

For 3DCP, placing of reinforcement for structural member (or for member with increased tensile strength) through embedded rebar or post-tensioning rebar is mostly manual. Moreover, keeping straight hollow voids for post-tensioning rebar would limit the shapes of architectural design [14]. The placement of reinforcement automatically and lack of guidelines are the barriers to the success of this new technology [58].

Another issue is the layering effect of 3DP process that produces uneven surfaces with the possibility of voids in between the layers. This is one of the major limitations of the 3DCP. Although this effect can be minimized with small layer thickness, it would need more time and energy to build the whole structure [14]. Guidelines should include different testing methods, the printed object size, and the minimum number of bead layers for objectively characterizing mechanical and durability properties.

Despite the potential benefits described in literature such as worksite safety, fast construction, low labor requirement, reduced waste, etc., Weinstein and Nawara [17] expressed their doubt about successful implementation of 3DCP in large scale for low cost/affordable housing development. The challenges include availability of low cost labors and local materials in developing countries that would be favorable against the high-tech dangerous materials needed for 3DCP method. Lack of proven success on the 3DCP in large-scale adoption is another ambiguity of this technology. Mechtcherine et al. [36] also mentioned that sufficient affordable labors are usually available in less developed countries though many of them are not skilled enough to build high-quality concrete structures. Moreover, as summarized in [59,60], the major challenges of adopting 3DCP include limited availability of automated fabrication technologies for large-scale construction, high initial cost of automated equipment, conventional design approaches are not suitable for automation, lack of sufficient quantity of suitable materials for 3DCP, and managerial issues with the conventional organizational structure.

$3 \mathrm{DCP}$ can be affected by the extreme weather. For example, most of the construction was performed at night for the largest 3D-printed building in Dubai due to the intense heat which reached $50{ }^{\circ} \mathrm{C}$ in June 2019 [61]. Moreover, as mentioned in [62], temperature and humidity changed significantly during the day and night so that the materials used in the printing process for this building had to withstand extreme heat and cold. Additionally, the constructor company (Apis Cor) realized the need to develop a printing medium that is suitable for extreme weather like in the UAE. Therefore, weather effects (e.g., extreme hot/cold, windy conditions, humidity, etc.) on 3DCP need to be explored in more detail to gain the full potential of this technology in construction.

While there is a little discussion on the foundation and base slab on which the initial layers are printed, typically, for on site construction, printing starts on a concrete slab which can be either cast-in-place, precast or prefab 3D-printed. For example, 3D-printed prefab concrete slabs were used as the bases of the 3D-printed walls for the construction of the largest 3D-printed building by Apis Cor [61]. On the other hand, for off-site printing, various printed building components are transported and assembled on site through bolting or other means of joining [15,63]. More detailed investigations are needed to see how different foundation/bases affect the quality of 3D-printed structures. 
Another challenge of automatic printing of a full-size structure (building, bridge, etc.) is the possibility of losses or accidents if there is any mistake in the design of 3D models or print parameters. Zuo et al. [64] experimented and suggested to conduct an evaluation of the model and parameters with a scale 3DP before starting the full-size 3D printing. Nevertheless, additional effort and cost of such evaluation have not been investigated in detail.

It is challenging to identify the robot location and setting working bases for 3DP with mobile robot [65]. To prevent unexpected collision, physical barrier might be necessary between human activities and the moving parts of the printing machine [14]. Often, a team of mobile robots may be employed concurrently in printing large structure for which proper planning and coordination of robots are necessary for optimal location and movement [66]. Accordingly, skilled personnel with the knowledge of programming, robot technology, and construction method is necessary. Particularly, the engineers are needed to be digitally savvy, able to perform advance computational analysis in the design process, and design verification of the structure [67].

Lastly, developing codes, standards and specifications for these non-traditional buildings, including public safety code standards pose further challenges to adopting 3DCP in large-scale [68]. Strauss [69] also argued that lack of legislation regulating 3D-printed structures is problematic for the additive manufactured houses, as any construction activities would follow such code of conduct in the event of injuries or fatalities.

\subsection{Worldwide 3D-Printed Construction}

After more than three decades of research on 3D printing in various domains, the interest of 3DP in construction has drastically increased in the recent years [14]. About 10 years ago, Lim et al. [70] described full-scale concrete printing with limited size $(5.4 \times 4.4 \times 5.4 \mathrm{~m})$ of building elements such as walls and facades. In 2014, WinSun Company in China successfully printed a number of houses in less than $24 \mathrm{~h} \mathrm{[16]}$. Despite the challenges of 3DCP, as discussed earlier, with the development of technologies and large-size 3D printers, the world has now witnessed many printed structures ranging from houses, offices, bridges, pavilions, shelters and many more [71]. Figure 3 presents some completed 3D-printed construction projects around the world that demonstrate the future potential for large-scale adoption of 3D printing in the construction industry. Moreover, the following sub-sections presents few world's renowned 3D-printed buildings and discusses key benefits and limitation of this innovative technology. 


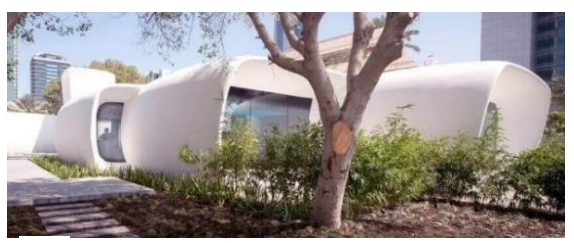

(a)

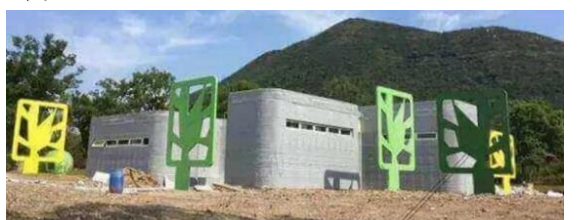

(b)

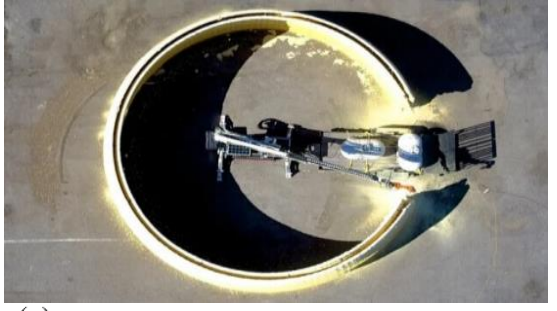

(c)

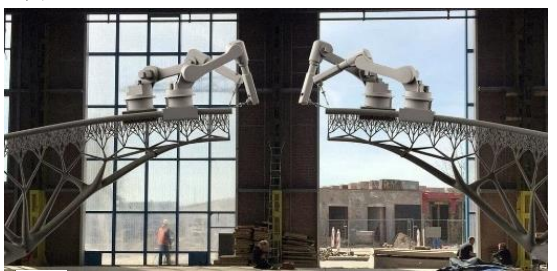

(d)

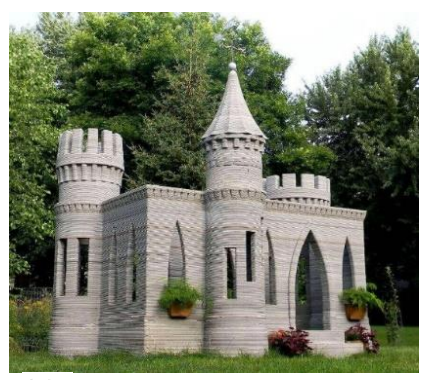

(e)

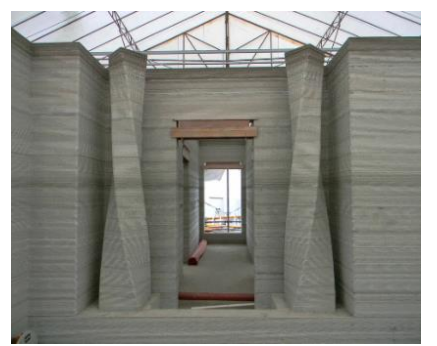

(f)

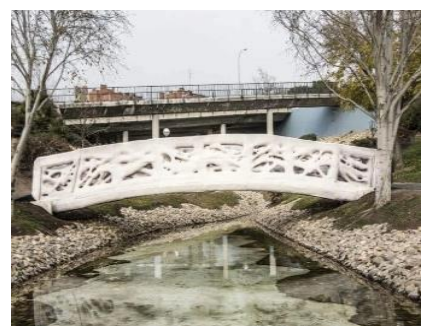

(g)

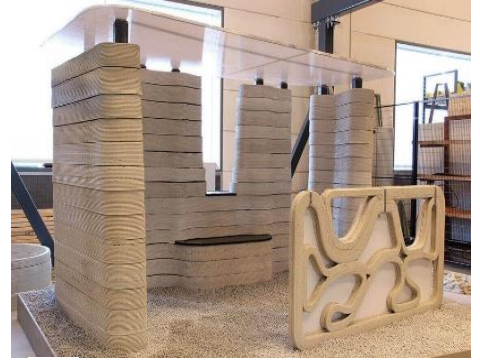

(h)

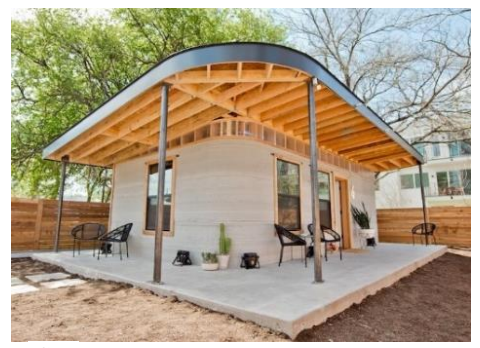

(i)

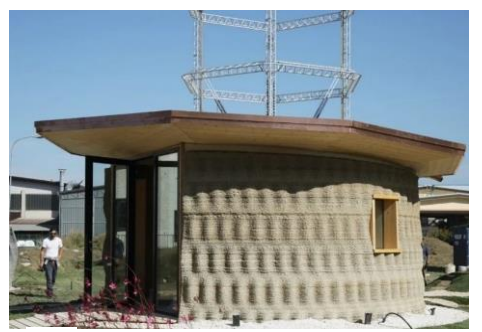

(j)

Figure 3. 3D-printed construction projects around the world (derived from [71-80]): (a) Office building in Dubai, UAE, completed in 2016; (b) Public restroom in Da Yang Mountain, China, completed in 2016; (c) 12-feet dome in California, USA, completed in 2017; (d) MX3D bridge in Amsterdam, Netherlands, completed in 2018; (e) First 3D-printed Castle in Minnesota, USA, completed in 2014; (f) Hotel in Manila, Philippines, completed in 2015; (g) Pedestrian Bridge in Madrid, Spain, completed in 2017; (h) TU Eindhoven Pavilion, Netherlands, completed in 2016; (i) Home for vulnerable people in Tabasco, Mexico; and (j) 3D-printed house with natural soil in Italy, completed in 2018.

\subsubsection{World's Largest 3D-Printed Building in Dubai by Apis Cor}

The 9.5-m-high and 640-square-meter floor space office building (Figure 4a) in Dubai, constructed by Apis Cor, is recognized as the largest 3D-printed building to date [81]. It is claimed that the construction was done using about half the usual craft workers and generated about $60 \%$ less waste [82]. The building was constructed much faster than a conventional construction project, particularly the 3D-printed parts that were printed on site, took only two weeks $[62,83]$. Nevertheless, as reported in [61], the printing time was about two months that include general contractor integrated ceiling, electronics and fittings. Additionally, the project took additional two months to finish after printing work was completed. In general, Table 2 presents different building components and their construction methods. As can be seen, all the walls that accounts the major concrete works of the building were 3D printed. Moreover, column formworks were also printed that saved significant laborious work and formwork materials. The rest of the construction works were done using conventional methods. Therefore, the potential of savings by 3D printing such as cut in construction costs by $50-70 \%$, labor costs by $50-80 \%$, and material waste by $60 \%$ [ 84 ] are only applicable to the building components that are 3D printed, not for the whole construction project. 


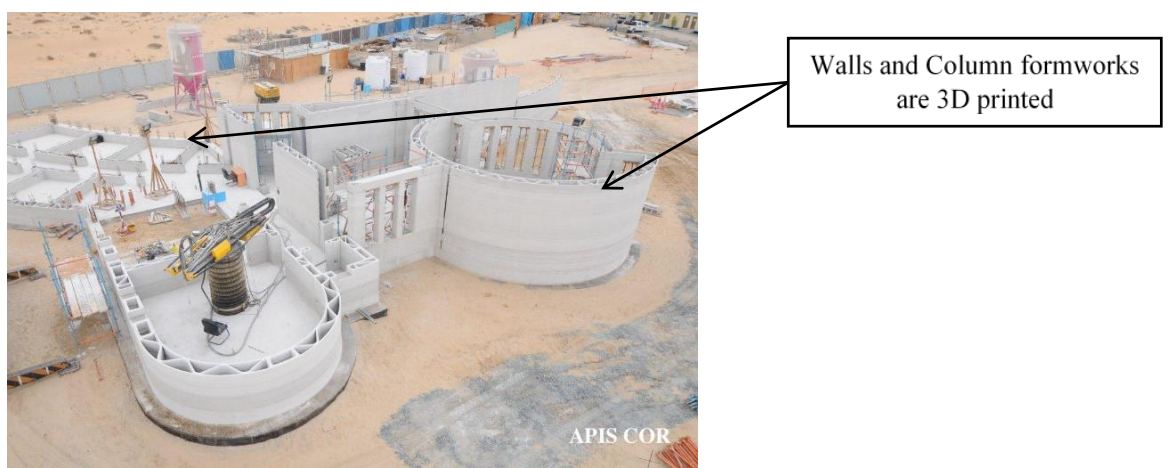

(a)
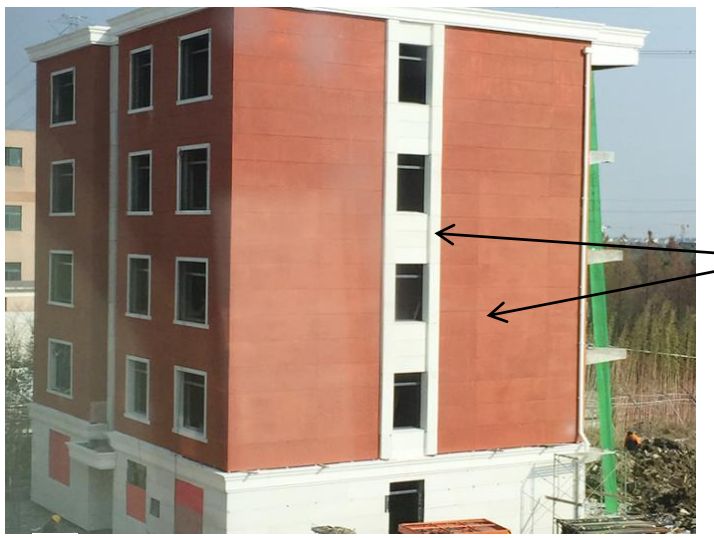

Walls and other structural members are $3 \mathrm{D}$ printed offsite and assembled on-site

(b)

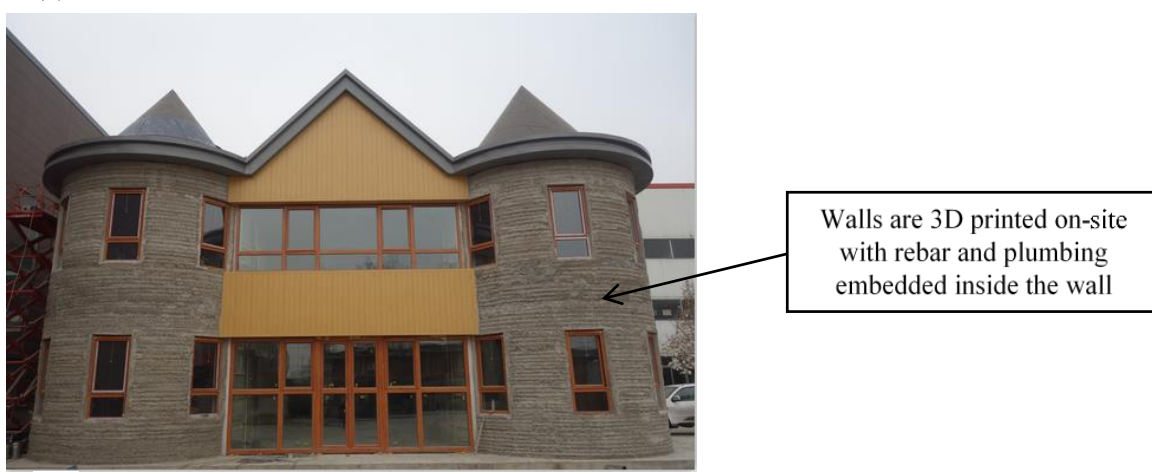

(c)

Figure 4. Few remarkable 3D-printed buildings (derived from [81,85,86]): (a) Construction of the largest 3D-printed building in Dubai; (b) World's highest 3D-printed building in China; and (c) Two-story house entirely printed on site.

Table 2. Construction methods of various components of the world's largest 3D-printed building.

\begin{tabular}{ll}
\hline Building Components & Construction Method \\
\hline $\begin{array}{l}\text { Foundation } \\
\text { Walls }\end{array}$ & Conventional construction method by general contractor \\
& 3D printed \\
\hline \multirow{3}{*}{ Columns } & -Reinforcements were placed manually \\
& -Formworks were 3D printed \\
\hline Slab & -Concreting was done manually \\
Roof, ceiling, windows, insulation & Precast \\
Plumbing and electrical installation & Conventional method by general contractor \\
\hline
\end{tabular}




\subsubsection{Global Highest 3D-Printed Building in China by WinSun}

The five-story apartment building (Figure $4 \mathrm{~b}$ ) constructed using 3D printing by WinSun is known as the world's highest 3D-printed building [85]. Various components of the building (Walls and other structural components) were printed off site as prefabricated elements and then transported and assembled on site $[15,63]$. Windows, doors and other finishing works were done using conventional methods. Although it was claimed that the construction processes saved construction time by $50-70 \%$, construction waste by $30-60 \%$, and labor costs by $50-80 \%$ [87], there was a strong contention about the claim [71].

\subsubsection{Two-Story House 3D Printed On Site}

Unlike the five-story highest 3D-printed building which was printed off site and assembled on site using steel reinforcement, this two-story house (Figure 4c) was printed entirely on site by HuaShang Tengda in China [86]. As mentioned in [63], off-site 3DCP might not be an attractive choice since a significant cost and labor would require for transportation and installation on site. A similar statement was also made in $[5,32]$ that the savings from modular buildings construction, especially for a less expensive home may be outweighed by the transportation cost.

Although the two-story house was printed on site, the whole construction was finished in a mere one and half months, including plumbing and other fittings. In contrast, a similar building with conventional method would take around 6-7 months.

The construction of this building followed rather a unique process of printing unlike other 3D-printed construction. First, the frame of the house was installed with rebar support and home's plumbing. Then printing was done with a gigantic 3D printer. Ordinary Class C 30 concrete was used without any additives. One of the important advantages of this concrete mix is that locally produced cement can be used that will reduce material transportation costs. Moreover, this structure is capable of withstanding earthquake of 8.0 magnitude [86].

\subsection{Prospect of $3 D C P$}

In recent time, Dubai has set a target to construct $25 \%$ of its buildings using 3DCP by $2030[23,61,82,84]$. The construction will include residential villas and stores, galleries, mobile homes and buildings for humanitarian causes, facilities and parks, foundations and construction joints, and lighting products. Although there are not enough showcases to decide about large-scale adoption of 3DCP, the success of the largest 3D-printed building in Dubai acclaimed that it has a great prospective as future construction innovation for the city [82]. The main driving force of 3DCP in Dubai is the potential savings in labor requirement since Dubai's construction is heavily dependent on migrant workers and they account about $90 \%$ of the workforce [61]. Other expected benefits include added economic value being one of the world leaders in 3DCP, productivity improvement with faster construction, and lower material cost by minimizing construction wastes.

The authors of [23] mentioned the prospect of 3D printing to make affordable houses to those in need. As reported in [88], it is planned to construct 50 houses using 3D printing in Tabaosco, Mexico, after the successful completion of two 3D-printed homes in just $24 \mathrm{~h}$ each. The housing is targeted for selected needy families who are living in extreme poverty with unsafe shelter in Tabaosco, Mexico. Each house is 500 square-foot (about 46 sq. meters) featured with a living room, two bedrooms, kitchen and bath.

The Asia-Pacific region has a great potential of adopting 3DCP in large scale. The driving factors include rising environmental and sustainability concerns, increasing urbanized population (particularly in China and India) along with the growth in disposable income, and efforts towards standardization [39]. Weinstein and Nawara [17] demonstrated that China and Saudi Arabia are the potential countries for market entry of the 3DCP which would be a subject of further investigation for how this technology can be implemented internationally. 
Housing demand is increasing with the rapid growth of population in developing countries and the conventional/traditional construction falls behind to meet this increasing demand [17]. Seventy-five percent of total construction volume are conventional masonry construction for the residential construction in Germany. This indicates that there is a high market potential of 3DCP in Germany. Additionally, this process is found to be highly competitive worldwide for building height up to five stories [36].

Metal 3D printing can also be used in construction that enables highly optimized structural forms and can be combined with traditional structural sections that make hybrid structures [67]. Nevertheless, the CAD process and post-processing for the surface finish and dimensional accuracy for many construction applications can be time consuming. These processing would require additional human intervention.

To gain the full potential of 3DCP, the scopes of the 3D printing works are to be enhanced for which research is ongoing to adopt in a large scale. For example, aluminum curtain wall components are 3D printed by a manufacturing company to be used for Rainier Square Tower in Seattle [68]. Buchanan and Gardner, and Camacho et al. [12,67] discussed about the possibility of metal 3D printing in construction such as façade/façade nodes, lighting nodes, metal bridge or other composite/hybrid structures.

To further expedite the construction process, high speed 3D printing technologies can be employed for which further research is desirable. In the manufacturing industry, high-speed 3D printing technologies are explored in recent time such as high-aspect-ratio nozzles for micro-extrusion [89]; integration of powder bed technology, multi-jet function technology, and high-speed sintering technology [90], to name a few. Moreover, as described in [91], special structural element such as lattice column and beam, or cellular structure which are suitable to construct using $3 \mathrm{D}$ printing, can be explored for the construction projects.

\section{Labor Market in Construction and Impact of 3DCP}

Traditionally, construction is very labor intensive and it accounts one of the major workforces around the world [3]. Labor also accounts for a major cost in construction projects [26]. In addition to that, shortage of manpower (skilled, semi-skilled and unskilled) and poor labor productivity are among the most important delay causes in construction projects [92]. Therefore, labor plays an important role in the construction industry. Nevertheless, physically demanding trades are less popular now a days among young people [31,93]. For skilled manual labor, fewer and fewer workers are available in the Central Europe [36]. A shortage of skilled workforce in the North American construction industry is common since the late 1980s [94]. Moreover, Albattah et al. [95] reported that the U.S. construction industry is losing workers from its craft worker pool at a faster rate than it is replenished. Labor shortage is also common in many other countries like Malaysia, Singapore, Qatar, UAE, etc. [27,93,96]. On the other hand, countries where there are ample of construction workers are still facing problems such as timely completion and quality construction due to the poor labor productivity $[97,98]$. Hence, this section first summarizes overall labor market situation in the construction industry around the world followed by the possible impact of 3DCP on the construction labor market.

\subsection{Issues with Shortage of Construction Labor}

According to the National Association of Home Builders/Wells Fargo surveys in the U.S., labor crunch is the biggest challenge and that it forced costs up 5.2\% over a 12-month period [5]. Karimi et al. [94] also reported that contractors are having difficulties in recruiting skilled craft workers for construction in the U.S. Similar to the USA, construction industry in many other countries are facing problems with the shortage of construction workers (especially skilled labors), particularly those who are dependent on immigrant workforces.

Many employers belief that immigrant employees are extremely hardworking, reliable, and willing to take risky, difficult, and low-paying jobs which others in the workforce would refuse [99]. The low pay to immigrant workforces further reduces production cost and product prices. As stated in [100], 
a $10 \%$ increase in low-skilled immigrant workforce in the U.S. labor market can decrease the prices of immigrant-intensive services by $2 \%$. Whereas, a $10 \%$ increase in immigrant construction workers in Norway can reduce the prices of construction services by $0.4-1.1 \%$ [101]. In contrast, immigrant workers were not necessarily employed to cut the cost in Malaysian construction industry, but were used due to the shortage of sufficient number of domestic workers [102].

Foreign workers become the most essential component of the labor market for the construction industry in Malaysia which accounts about $70 \%$ of its workforce $[93,102]$. The same is true for Singapore, Brunei, and most of the middle-east countries [27,103]. For example, Doha is facing a major challenge in finding huge workforce needed to complete its World Cup project program since construction in Qatar is heavily dependent on migrated workers [96]. In Singapore, 293.3 thousand construction workers were non-resident/immigrants as in the year 2019, which accounts around $75 \%$ of the total construction workforce [104]. The United Arab Emirates (UAE) also had difficulties to meet construction deadlines due to the knock-on effects of the clampdown on illegal immigrants [27]. As stated in [99], foreign workers have played an important role on most of the construction projects in the USA. A study by Iskander and Lowe [105] depicted that the Latino immigrants alone made up around 75\% workforce of the state's urban construction in Raleigh-Durham.

There are many illegal migrants which is a big concern for a country that is dependent on foreign construction workers. Twenty-five percent of general construction laborers are illegal in the USA [99]. Another study by Golden and Skibniewski [106] claimed that 19\% of all illegal immigrants (about 11 million) work in the construction industry that comprised around $14 \%$ of all construction employees. In Washington D.C. metropolitan area, about 55\% of low-skilled construction workforces are illegal. As reported in [5], the recent proposal by the U.S. president to crack down on illegal workers may further squeeze the construction industry since it is heavily dependent on immigrant workers. For example, a depletion of immigrant labor supply could increase overall labor costs for projects by almost $18 \%$, and could rise the total project costs by around 12\% in the Washington D.C. metropolitan areas [106]. Malaysian construction experienced a labor crisis in 2002 when almost 400,000 illegal workers were deported as part of massive repatriation exercise by the government. Consequently, the government were forced to rescind the order due to the major disruptions in construction [102]. Around 100,000 illegal immigrants are working in Qatar construction industry [96]. The government initiatives to deport these illegal immigrants would significantly hamper the construction projects in Qatar. Accordingly, the construction industry in Qatar demands relaxing regulations on government requirements.

While the large companies may be able to cope the increased costs for its project due to the shortage of immigrant workers, small and medium companies or subcontractors are unlikely to absorb the significant increase (as much as 11-67\%) in labor costs [106].

Over reliance on immigrant workforce is highly undesirable. Any disruption of supply according to the industry's demand can undermine the country's economy like Malaysia [102]. Countries like UAE and Qatar faced a similar situation in the recent past [27,96]. Moreover, foreign workers are highly vulnerable to work related accidents, injuries and fatalities. As reported in [107], foreign construction workers have more fatalities at work, as much as twice compared to native-born workers.

\section{Skilled Labor Challenges in Construction}

Finding skilled labors may not be a big issue for large companies since they have better job contracts. However, Small and Medium companies often face challenges to find skilled labors. Moreover, not all companies get a complete Return on Investment from the training on construction courses or special skills [98]. This is because, many construction workers are hired on project or ad hoc basis and often they frequently move from company to company. In the case of immigrant workers, often skills gained on the job are lost when they return home [102].

This shortage of skilled labor can be overcome with the use of technology such as 3DCP. Unlike labor workforces, a 3D printing machine/robot can work $24 \mathrm{~h}$ a day. Therefore, it can continue to work 
until the task is completed with significantly less number of people (skilled operator) to be present on site as opposed to dozens of workers [108].

\subsection{Organizational Structure for 3DCP}

Considering the nature of 3DP in construction, the design and work processes, the organizational structures are to be re-assessed. As queried in [68], 3DCP will reduce the number of architects, engineers, and constructors needed to design and plan a construction project or only the number of craft workers on the jobsite. Although it has not been investigated if less people will be required during the design and planning stage, it is evident from the literature that especial skills are to be acquired to adopt 3DCP within an organization. Accordingly, the organizational structure and workflow can be rearranged to adopt $3 \mathrm{DCP} /$ digital fabrication (dfab) compared to the conventional construction, as shown in Figure 5. This rearrangement has been derived from Schutter et al. [59]. In the conventional construction workflow, design is followed by construction of the physical structure which is done by a bunch of general and specialized workforces under the construction manager(s). In contrast, both the design and construction processes are different for 3DCP. In this case, a dfab manager handles both the design and construction phases because these two phases are tightly integrated and the digital model developed in the design stage is directly converted into a 3D printable format to print the physical structure. In the construction stage, most of the laborious works are replaced with the printing process which is done by dfab programmer and some workers with especial skills related to 3DCP. It is to be noted that the number of human resources shown in Figure 5 are illustrative in both organizational structures. Actual number of people required in the case of 3DCP can vary depending on the construction methods (e.g., on- or off-site printing), printing technology, material used, etc., for which further research is warranted.

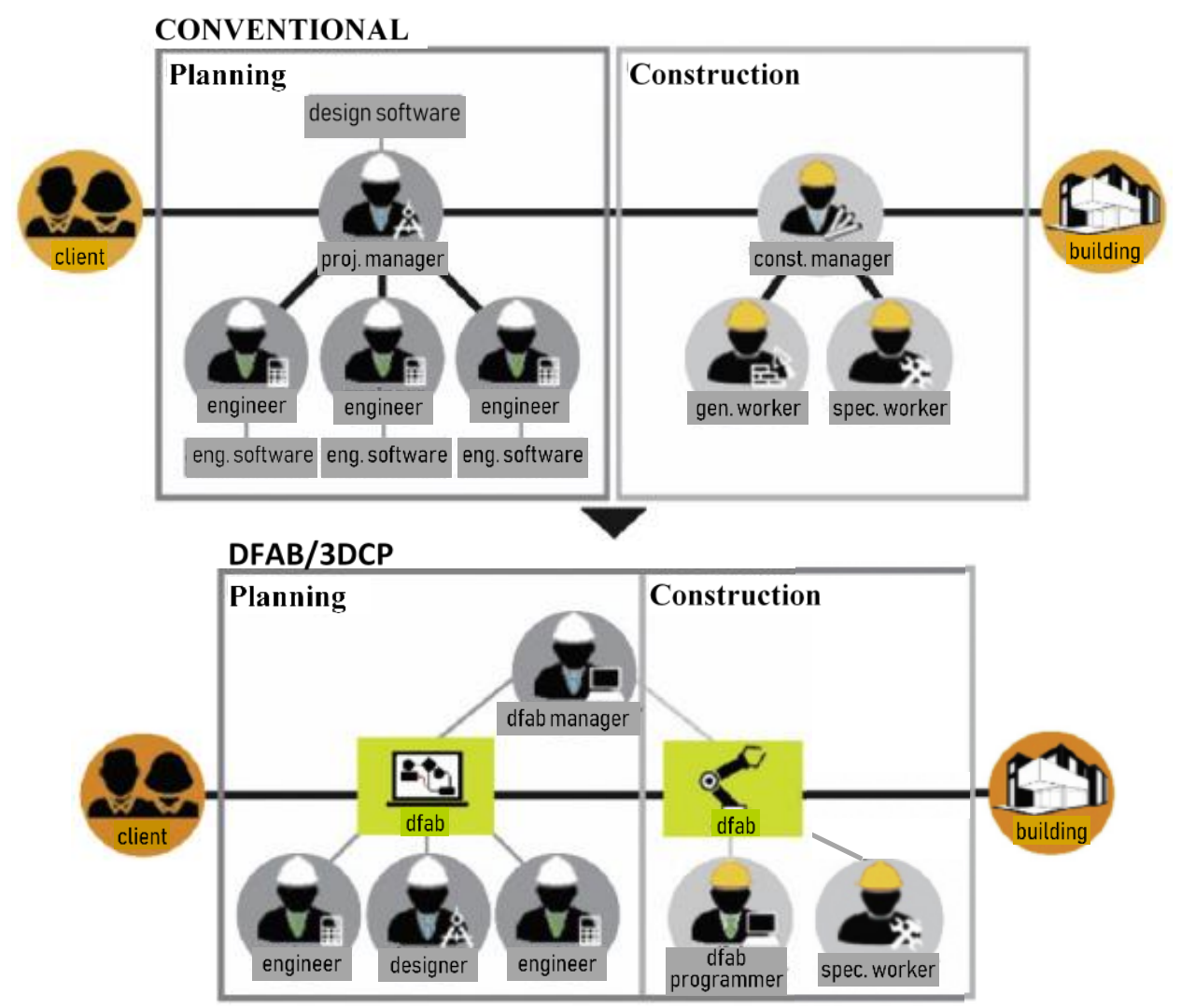

Figure 5. Organizational Structure and workflow for conventional vs. dfab/3DCP (derived from Schutter et al. [59]). 


\section{Discussion}

While it is expected that less human resources would be required for 3DCP, it will also require people with special skills who understand both masonry and digital technology so that they are able to detect glitches in the digital model during the masonry construction [31]. To work with 3D printing, they should be able to integrate robotic and civil works. With the increasing adoption of 3DCP, existing workers would need necessary training to cope with the new working processes of 3DCP or may choose moving to other jobs $[14,108]$.

Large-scale adoption of 3DCP would cut jobs of many construction workers, particularly the basic low-skilled job positions. This will be beneficial for the companies who are predominantly dependent on migrated workers where shortage of labor is a big concern. On the other hand, these jobs cut can be problematic for the countries where sufficient labors are available and the construction industry is one of the major sources of employment. Often, construction workers receive higher payment than other workforces. For example, the average salary in the construction industry is higher than the average salary among other professions in Kazakhstan. As reported in [93], construction workers are paid relatively higher than other industries, since they are often hired on ad hoc basis with the lack of social protection.

The elimination of job can be detrimental to the specialists in construction works; however, other sides of technological innovation also should be considered. For instance, as low-skilled jobs are occupied by machines, it can positively enhance and upgrade the list of professions with more sophisticated list of duties, such as 3D design/modeling, 3D printer supervising, material quality control, research and development, legal advising (due to the lack of legislations and indeterminacy of liability for emergency situations with 3D-printed structures), etc. Moreover, implementation of 3DCP is proved to save workers from possible hazardous environment involved in construction activities. Being one of the dangerous industries in term of worksite safety and health, construction industry experience the most number of fatal injuries in the U.S. [107]. 3DCP can eliminate/minimize the number of labor requirement from risky works in the construction process.

Another point of consideration is that there is a still a big deal of argument on how much 3DP can do in construction projects and the potential savings as claimed in various literature might be overrated. This is because, for off-site 3DCP, individual walls, floors, roof and other building elements are printed which are needed to be fastened together by the means of conventional methods such bolting/joining parts together. Even the entire structure of a building is printed using 3DP technology (on site printing), much of the interior and exterior of the house such as installation of mechanical, electrical and plumbing (MEP) items, plastering, and other finishes are to be done using conventional method, rather than printed [109].

Finally, new technology is and will continue to affect the construction industry in various ways. Innovative technologies such as robots, drones and 3D printing help to gain the speed and efficiency of construction works. However, it does not necessarily replace the human workers, instead will continue to work alongside as a team [110].

\section{Conclusions}

Construction is one of the labor-intensive industries which is characterized by low productivity with low technological usage. Along with robotics and other automation technologies, 3DP has received increasing attention in construction. This study made a comprehensive review on the current progress and future prospects of 3D printing in construction. With the possibility of large-scale adoption of 3DCP, this paper also investigated how the construction labor market would be affected by this technology. It is evident from the literature that $3 \mathrm{DCP}$ has a great potential to positively influence the construction industry such as fast construction, reduced material waste, less intense labor requirements, improved worksite safety, etc. Although the use of 3DP in construction is still in the research and development stage with very limited number of buildings and small bridges are found for practical use around the world, the literature showed that more and more constructions are to be done with 3DCP in the coming 
years. As Dubai has announced that $25 \%$ of its buildings are to be constructed using this innovative technology by 2030, the market of 3DCP is expected to grow in other countries as well.

The literature suggests that $3 \mathrm{DCP}$ significantly reduces the number of labors in the construction process and could save labor costs by $50-80 \%$. Therefore, it is expected that the 3DCP can solve the labor shortage problem, especially for the countries like USA, UAE, Qatar, Malaysia, Singapore, etc., where construction is heavily dependent on migrated workers. On the other hand, jobs cut due to the use of 3DCP can be detrimental for the countries where construction is one of the major workforces. Nevertheless, use of this technology would create the opportunity for other sophisticated jobs with special skills. Moreover, as mentioned in [110], new technologies help to gain speed and efficacy of construction works and these technologies work along with human as a team. Further research is needed to see the actual interaction between human resources and 3DCP technology when large-scale construction will be done with 3D printing.

Another challenge of adopting 3DCP in large-scale is the costs of infrastructure to be acquired by the construction companies. The cost saving gained from 3DCP mainly include material, labor and time savings, without accounting the detail costs of machines (3D printer/robots) and necessary software, hardware, training, etc. As can be seen for Building Information Modeling (BIM), despite the huge benefits BIM offer to the construction projects, many construction companies, especially in developing countries are yet to implement this technology due to the large costs involved for software, hardware, and training, etc. [111]. Therefore, additional costs of 3DCP may outweigh the savings, particularly where labor is less expensive. A more detailed investigation is necessary to find a suitable trade off.

Author Contributions: Conceptualization, M.A.H., A.Z., S.C.P. and J.R.K.; methodology, M.A.H., A.Z. and S.C.P.; validation, M.A.H., and A.Z.; formal analysis, M.A.H., A.Z.; investigation, M.A.H.; writing-original draft preparation, M.A.H., A.Z. and S.C.P; writing-review and editing, M.A.H., and J.R.K.; visualization, M.A.H., A.Z. and S.C.P.; supervision, M.A.H.; funding acquisition, J.R.K. All authors have read and agreed to the published version of the manuscript.

Funding: This research was supported by the Nazarbayev University Research Fund under Grants \#SOE2017003. The authors are grateful for this support. Any opinions, findings, and conclusions or recommendations expressed in this material are those of the author(s) and do not necessarily reflect the views of the Nazarbayev University.

Conflicts of Interest: The authors declare no conflict of interest.

\section{References}

1. Crosthwaite, D. The global construction market: A cross-sectional analysis. Constr. Manag. Econ. 2000, 18, 619-627. [CrossRef]

2. Horta, I.M.; Camanho, A.S.; Jill, J.; Geraint, J. Performance trends in the construction industry worldwide: An overview of the turn of the century. J. Product. Anal. 2013, 39, 89-99. [CrossRef]

3. Which Sector Will Create The Most Jobs? Available online: https://www.ilo.org/global/about-the-ilo/ multimedia/maps-and-charts/WCMS_337082/lang--en/index.htm (accessed on 1 July 2020).

4. Global Construction Expenditures 2014-2025. Available online: https://www.statista.com/statistics/788128/ construction-spending-worldwide/ (accessed on 1 July 2020).

5. Woetzel, J.; Sridhar, M.; Mischke, J. The Construction Industry Has a Productivity Problem—And Here's How to Solve It. Available online: https:/www.marketwatch.com/story/the-construction-industry-has-aproductivity-problem-and-heres-how-to-solve-it-2017-03-04 (accessed on 1 July 2020).

6. Changali, S.; Mohammad, A.; Nieuwland, M.v. The Construction Prductivity Imperative. Available online: https://www.mckinsey.com/industries/capital-projects-and-infrastructure/our-insights/theconstruction-productivity-imperative\# (accessed on 1 July 2020).

7. Construction Productivity Versus Manufacturing Productivity. Available online: https://ledgerwoodusa. com/construction-productivity-versus-manufacturing-productivity/ (accessed on 1 July 2020).

8. Cai, S.; Ma, Z.; Skibniewski, M.J.; Bao, S. Construction automation and robotics for high-rise buildings over the past decades: A comprehensive review. Adv. Eng. Inform. 2019, 42, 100989. [CrossRef] 
9. Hofmann, E.; Rüsch, M. Industry 4.0 and the current status as well as future prospects on logistics. Comput. Ind. 2017, 89, 23-34. [CrossRef]

10. Davila Delgado, J.M.; Oyedele, L.; Ajayi, A.; Akanbi, L.; Akinade, O.; Bilal, M.; Owolabi, H. Robotics and automated systems in construction: Understanding industry-specific challenges for adoption. J. Build. Eng. 2019, 26, 100868. [CrossRef]

11. Bock, T. The future of construction automation: Technological disruption and the upcoming ubiquity of robotics. Autom. Constr. 2015, 59, 113-121. [CrossRef]

12. Delgado Camacho, D.; Clayton, P.; O’Brien, W.J.; Seepersad, C.; Juenger, M.; Ferron, R.; Salamone, S. Applications of additive manufacturing in the construction industry-A forward-looking review. Autom. Constr. 2018, 89, 110-119. [CrossRef]

13. Rayna, T.; Striukova, L. From rapid prototyping to home fabrication: How 3D printing is changing business model innovation. Technol. Forecast. Soc. Chang. 2016, 102, 214-224. [CrossRef]

14. Tay, Y.W.D.; Panda, B.; Paul, S.C.; Noor Mohamed, N.A.; Tan, M.J.; Leong, K.F. 3D printing trends in building and construction industry: A review. Virtual Phys. Prototyp. 2017, 12, 261-276. [CrossRef]

15. Hager, I.; Golonka, A.; Putanowicz, R. 3D Printing of Buildings and Building Components as the Future of Sustainable Construction? Procedia Eng. 2016, 151, 292-299. [CrossRef]

16. Wu, P.; Wang, J.; Wang, X. A critical review of the use of 3-D printing in the construction industry. Autom. Constr. 2016, 68, 21-31. [CrossRef]

17. Weinstein, D.; Nawara, P. Determining the Applicability of 3D Concrete Construction (Contour Crafting) of Low Income Houses in Select Countries. Cornell Real Estate Rev. 2015, 13, 94-111.

18. Zhang, J.; Wang, J.; Dong, S.; Yu, X.; Han, B. A review of the current progress and application of 3D printed concrete. Compos. Part A Appl. Sci. Manuf. 2019, 125, 105533. [CrossRef]

19. 3D Printing And Its Application in the Construction Industry. Available online: https://www.ennomotive. com/3d-printing-and-its-application-in-the-construction-industry/ (accessed on 1 July 2020).

20. Xu, J.; Ding, L.; Love, P.E.D. Digital reproduction of historical building ornamental components: From 3D scanning to 3D printing. Autom. Constr. 2017, 76, 85-96. [CrossRef]

21. Singha, K. 7 Advantages of Using a 3D Printer in Construction Projects. Available online: https://constructionreviewonline.com/2020/04/7-advantages-of-using-a-3d-printer-in-construction-projects/ (accessed on 1 July 2020).

22. Agustí-Juan, I.; Habert, G. Environmental design guidelines for digital fabrication. J. Clean. Prod. 2017, 142, 2780-2791. [CrossRef]

23. Saleem, F. World's Largest 3D-Printed Building in Dubai. Available online: https://www.engineering.com/ BIM/ArticleID/19863/Worlds-Largest-3D-Printed-Building-in-Dubai.aspx (accessed on 1 July 2020).

24. Tractica. Construction Robotics Market to Reach \$226 Million Worldwide by 2025. 2019. Available online: https://tractica.omdia.com/newsroom/press-releases/construction-robotics-market-to-reach-226million-worldwide-by-2025/ (accessed on 1 July 2020).

25. García de Soto, B.; Agustí-Juan, I.; Hunhevicz, J.; Joss, S.; Graser, K.; Habert, G.; Adey, B.T. Productivity of digital fabrication in construction: Cost and time analysis of a robotically built wall. Autom. Constr. 2018, 92, 297-311. [CrossRef]

26. Jang, H.; Kim, K.; Kim, J.H.; Kim, J. Labour productivity model for reinforced concrete construction projects. Constr. Innov. Inf. Process Manag. 2011, 11, 92-113. [CrossRef]

27. Labour shortage hits contractors. Meed Middle East Econ. Dig. 2007, 51, 16. Available online: https://www.masader.om/eds/detail?db=awr\&an=26885902\&isbn=00477230 (accessed on 1 July 2020).

28. Kim, M.J.; Chi, H.-L.; Wang, X.; Ding, L. Automation and Robotics in Construction and Civil Engineering. J. Intell. Robot. Syst. 2015, 79, 347-350. [CrossRef]

29. Berry, T. The First Hydraulic Excavators. Available online: https://www.oemoffhighway.com/fluid-power/ article/12022256/the-first-hydraulic-excavators (accessed on 1 July 2020).

30. Concrete Pumps. Available online: http://www.schwing-stetter.co.uk/Pages/ConcretePumpingOverview. aspx (accessed on 1 July 2020).

31. Brehm, E. Robots for masonry construction-Status quo and thoughts for the German market. Mauerwerk 2019, 23, 87-94. [CrossRef]

32. Grigoryan, E.A.; Semenova, M.D. Automation of the construction process by using a hinged robot with interchangeable nozzles. Mater. Today Proc. 2020. [CrossRef] 
33. Hodson, H. Robo-builders deliver architects' dreams. New Sci. 2013, 218, 22-23. Available online: https://www.newscientist.com/article/mg21829135-600-robot-builders-deliver-architects-dreams/ (accessed on 1 July 2020).

34. Kahane, B.; Rosenfeld, Y. Balancing Human-and-Robot Integration in Building Tasks. Comput. -Aided Civ. Infrastruct. Eng. 2004, 19, 393-410. [CrossRef]

35. Yang, H.; Chung, J.K.H.; Chen, Y.; Li, Y. The cost calculation method of construction 3D printing aligned with internet of things. EURASIP J. Wirel. Commun. Netw. 2018, 147. [CrossRef]

36. Mechtcherine, V.; Nerella, V.N.; Will, F.; Näther, M.; Otto, J.; Krause, M. Large-scale digital concrete construction-CONPrint3D concept for on-site, monolithic 3D-printing. Autom. Constr. 2019, 107, 102933. [CrossRef]

37. Jarkas, A.M. Effect of Buildability on Labor Productivity: A Practical Quantification Approach. J. Constr. Eng. Manag. 2016, 142, 06015002. [CrossRef]

38. Proverbs, D.G.; Holt, G.D.; Olomolaiye, P.O. Productivity rates and construction methods for high rise concrete construction: A comparative evaluation of UK, German and French contractors. Constr. Manag. Econ. 1999, 17, 45-52. [CrossRef]

39. 3D Concrete Printing Market to Reach \$ 56.4 Million by 2021. Available online: https://www.3printr.com/3dconcrete-printing-market-reach-56-4-million-2021-1239664/ (accessed on 1 July 2020).

40. Allouzi, R.; Al-Azhari, W.; Allouzi, R. Conventional Construction and 3D Printing: A Comparison Study on Material Cost in Jordan. J. Eng. 2020, 2020, 1424682. [CrossRef]

41. Nadarajah, N. Development of concrete 3D Printing. Master's Thesis, Aalto University, Espoo, Finland, 2018.

42. 3D Printing in Construction Market Forecast (2020-2025). Available online: https://www.industryarc.com/ Report/18132/3d-printing-in-construction-market.html (accessed on 1 July 2020).

43. Kruger, J.; Zeranka, S.; van Zijl, G. A rheology-based quasi-static shape retention model for digitally fabricated concrete. Constr. Build. Mater. 2020, 254, 119241. [CrossRef]

44. Panda, B.; Tan, M.J. Experimental study on mix proportion and fresh properties of fly ash based geopolymer for 3D concrete printing. Ceram. Int. 2018, 44, 10258-10265. [CrossRef]

45. Nerella, V.N.; Mechtcherine, V. Studying the Printability of Fresh Concrete for Formwork-Free Concrete Onsite 3D Printing Technology (CONPrint3D). In 3D Concrete Printing Technology; Sanjayan, J.G., Nazari, A., Nematollahi, B., Eds.; Butterworth-Heinemann: Oxford, UK, 2019; pp. 333-347. [CrossRef]

46. Rushing, T.S.; Stynoski, P.B.; Barna, L.A.; Al-Chaar, G.K.; Burroughs, J.F.; Shannon, J.D.; Kreiger, M.A.; Case, M.P. Investigation of Concrete Mixtures for Additive Construction. In 3D Concrete Printing Technology; Sanjayan, J.G., Nazari, A., Nematollahi, B., Eds.; Butterworth-Heinemann: Oxford, UK, 2019; pp. 137-160. [CrossRef]

47. Roussel, N. Rheological requirements for printable concretes. Cem. Concr. Res. 2018, 112, 76-85. [CrossRef]

48. Panda, B.; Ruan, S.; Unluer, C.; Tan, M.J. Improving the 3D printability of high volume fly ash mixtures via the use of nano attapulgite clay. Compos. Part B Eng. 2019, 165, 75-83. [CrossRef]

49. Paul, S.C.; Tay, Y.W.D.; Panda, B.; Tan, M.J. Fresh and hardened properties of 3D printable cementitious materials for building and construction. Arch. Civ. Mech. Eng. 2018, 18, 311-319. [CrossRef]

50. Khalil, N.; Aouad, G.; El Cheikh, K.; Rémond, S. Use of calcium sulfoaluminate cements for setting control of 3D-printing mortars. Constr. Build. Mater. 2017, 157, 382-391. [CrossRef]

51. Chen, Y.; Li, Z.; Chaves Figueiredo, S.; Çopuroğlu, O.; Veer, F.; Schlangen, E. Limestone and Calcined Clay-Based Sustainable Cementitious Materials for 3D Concrete Printing: A Fundamental Study of Extrudability and Early-Age Strength Development. Appl. Sci. 2019, 9, 1809. [CrossRef]

52. Ogura, H.; Nerella, V.N.; Mechtcherine, V. Developing and Testing of Strain-Hardening Cement-Based Composites (SHCC) in the Context of 3D-Printing. Materials 2018, 11, 1375. [CrossRef]

53. Marchment, T.; Sanjayan, J.; Xia, M. Method of enhancing interlayer bond strength in construction scale 3D printing with mortar by effective bond area amplification. Mater. Des. 2019, 169, 107684. [CrossRef]

54. Jayathilakage, R.; Sanjayan, J.; Rajeev, P. Direct shear test for the assessment of rheological parameters of concrete for 3D printing applications. Mater. Struct. 2019, 52, 12. [CrossRef]

55. Jeong, H.; Han, S.-J.; Choi, S.-H.; Lee, Y.J.; Yi, S.T.; Kim, K.S. Rheological Property Criteria for Buildable 3D Printing Concrete. Materials 2019, 12, 657. [CrossRef] 
56. Nerella, V.N.; Hempel, S.; Mechtcherine, V. Effects of layer-interface properties on mechanical performance of concrete elements produced by extrusion-based 3D-printing. Constr. Build. Mater. 2019, 205, 586-601. [CrossRef]

57. Panda, B.; Chandra Paul, S.; Jen Tan, M. Anisotropic mechanical performance of 3D printed fiber reinforced sustainable construction material. Mater. Lett. 2017, 209, 146-149. [CrossRef]

58. Paul Suvash, C.; van Zijl Gideon, P.A.G.; Tan Ming, J.; Gibson, I. A review of 3D concrete printing systems and materials properties: Current status and future research prospects. Rapid Prototyp. J. 2018, 24, 784-798. [CrossRef]

59. De Schutter, G.; Lesage, K.; Mechtcherine, V.; Nerella, V.N.; Habert, G.; Agusti-Juan, I. Vision of 3D printing with concrete-Technical, economic and environmental potentials. Cem. Concr. Res. 2018, 112, 25-36. [CrossRef]

60. Perkins, I.; Skitmore, M. Three-dimensional printing in the construction industry: A review. Int. J. Constr. Manag. 2015, 15, 1-9. [CrossRef]

61. Molitch-Hou, M. "World's Largest" 3D Printed Building Unveiled in Dubai. Available online: https://3dprint.com/261978/worlds-largest-3d-printed-building-unveiled-in-dubai-d/ (accessed on 1 July 2020).

62. Jewell, N. World's Largest 3D-Printed Building Opens in Dubai after 2 Weeks of Construction. Available online: https://inhabitat.com/worlds-largest-3d-printed-building-opens-in-dubai-after-2-weeksof-construction/ (accessed on 1 July 2020).

63. Augur, H. This On-Site 3D Printed House Took Only 45 Days. Available online: https://all3dp.com/21776-2/ (accessed on 1 July 2020).

64. Zuo, Z.; Gong, J.; Huang, Y.; Zhan, Y.; Gong, M.; Zhang, L. Experimental research on transition from scale 3D printing to full-size printing in construction. Constr. Build. Mater. 2019, 208, 350-360. [CrossRef]

65. Subrin, K.; Bressac, T.; Garnier, S.; Ambiehl, A.; Paquet, E.; Furet, B. Improvement of the mobile robot location dedicated for habitable house construction by 3D printing. IFAC -PapersOnLine 2018, 51, 716-721. [CrossRef]

66. Zhang, X.; Li, M.; Lim, J.H.; Weng, Y.; Tay, Y.W.D.; Pham, H.; Pham, Q.-C. Large-scale 3D printing by a team of mobile robots. Autom. Constr. 2018, 95, 98-106. [CrossRef]

67. Buchanan, C.; Gardner, L. Metal 3D printing in construction: A review of methods, research, applications, opportunities and challenges. Eng. Struct. 2019, 180, 332-348. [CrossRef]

68. Smith, C. 3-D Printing Reshaping Construction Industry. Available online: https://www.dcd.com/articles/3d-printing-reshaping-construction-industry (accessed on 1 July 2020).

69. Strauss, H. AM Envelope: The Potential of Additive Manufacturing for Facade Constructions. Ph.D. Thesis, Delft University of Technology, Delft, The Netherlands, 2013.

70. Lim, S.; Buswell, R.A.; Le, T.T.; Austin, S.A.; Gibb, A.G.F.; Thorpe, T. Developments in construction-scale additive manufacturing processes. Autom. Constr. 2012, 21, 262-268. [CrossRef]

71. 3D Printed House: Most Important Projects. Available online: https://all3dp.com/2/3d-printed-house-3dprinted-building/ (accessed on 1 July 2020).

72. Zoey. WinSun-Print into the Future. Available online: https://digital.hbs.edu/platform-rctom/submission/ winsun-print-into-the-future/ (accessed on 20 September 2020).

73. Clark, C. Chinese Construction Company Gets Dirty With Tech: Unveils 3D Printed Public Restroom. Available online: https://zbrella.com/blog/chinese-construction-company-gets-dirty-tech-unveils3d-printed-public-restroom/ (accessed on 20 September 2020).

74. Yurieff, K. This Robot Can 3D Print a Building in 14 Hours. Available online: https://money.cnn.com/2017/05/ 02/technology/3d-printed-building-mit/index.html (accessed on 20 September 2020).

75. Wang, L. Amsterdam's New 3D-Printed Steel Bridge Is Revolutionizing the Building Industry. Available online: https://inhabitat.com/amsterdams-new-bridge-will-be-made-of-3d-printed-steel/3d-printed-steelbridge-amsterdam-4/ (accessed on 20 September 2020).

76. Marquart, S. This Hotel Is 3D Printed from Sand and Volcanic Ash. Available online: https://futurism.com/ hotel-3d-printed-sand-volcanic-ash (accessed on 20 September 2020).

77. Valencia, N. World's First 3D Printed Bridge Opens in Spain. Available online: https://www.archdaily.com/ 804596/worlds-first-3d-printed-bridge-opens-in-spain (accessed on 20 September 2020).

78. O'Neal, B. Eindhoven University of Technology (TU/e) Unveils Massive Robotic Concrete 3D Printer, Displays New Pavilion. Available online: https://3dprint.com/139988/tue-concrete-3d-printer-pavilion/ (accessed on 20 September 2020). 
79. Bendix, A. These 3D-Printed Homes Can Be Built for Less Than $\$ 4,000$ in Just 24 Hours. Available online: https://www.businessinsider.com/3d-homes-that-take-24-hours-and-less-than-4000-to-print-2018-9 (accessed on 20 September 2020).

80. Gaia: The First House 3D-Printed With Earth. Available online: https://industryeurope.com/the-first-house3dprinted-with-earth/ (accessed on 20 September 2020).

81. Collaborative Project with Dubai Municipality. Available online: https://www.apis-cor.com/dubai-project (accessed on 1 July 2020).

82. Carlota, V. Apis Cor Collaborates on World's Largest 3D Printed Building. Available online: https://www.3dnatives.com/en/apis-cor-largest-3d-printed-building-261020194/\#! (accessed on 1 July 2020).

83. Bravo, E. An Administrative Building in Dubai, the Largest 3D Printed Structure in the World. Available online: https://www.smartcitylab.com/blog/digital-transformation/largest-3d-printed-building-inthe-world/ (accessed on 1 July 2020).

84. 25\% of Dubai Buildings Will Be 3D Printed by 2030. Available online: https://www.arch2o.com/25-dubaibuildings-will-3d-printed-2030/ (accessed on 1 July 2020).

85. 2015 Global Highest 3D Printing Building. Available online: http://www.winsun3d.com/En/Product/pro_ inner_5/id/102 (accessed on 1 July 2020).

86. Scott, C. Chinese Construction Company 3D Prints an Entire Two-Story House On-Site in 45 Days. Available online: https://3dprint.com/138664/huashang-tengda-3d-print-house/ (accessed on 1 July 2020).

87. Made in China: World's First 3D-Printed Apartment Complex. Available online: https://weburbanist.com/ 2015/01/20/made-in-china-worlds-first-3d-printed-apartment-complex/ (accessed on 1 July 2020).

88. New Story. Available online: https://newstorycharity.org/press-kit/ (accessed on 1 July 2020).

89. Shaw, L.; Islam, M.; Li, J.; Li, L.; Ayub, S.M.I. High-Speed Additive Manufacturing Through High-Aspect-Ratio Nozzles. JOM J. Miner. Met. Mater. Soc. 2018, 70, 284. [CrossRef]

90. Nazir, A.; Jeng, J.-Y. A high-speed additive manufacturing approach for achieving high printing speed and accuracy. Proc. Inst. Mech. Eng. Part C J. Mech. Eng. Sci. 2019, 234, 2741-2749. [CrossRef]

91. Aamer, N.; Ahmad Bin, A.; Jeng-Ywan, J. Buckling and Post-Buckling Behavior of Uniform and Variable-Density Lattice Columns Fabricated Using Additive Manufacturing. Materials 2019, 12, 3539. [CrossRef]

92. Hossain, M.A.; Raiymbekov, D.; Nadeem, A.; Kim, J.R. Delay causes in Kazakhstan's construction projects and remedial measures. Int. J. Constr. Manag. 2019, 1-19. [CrossRef]

93. Abdul-Aziz, A.-R. Foreign workers and labour segmentation in Malaysia's construction industry. Constr. Manag. Econ. 2001, 19, 789-798. [CrossRef]

94. Karimi, H.; Taylor, T.; Goodrum, P.; Srinivasan, C. Quantitative analysis of the impact of craft worker availability on construction project safety performance. Constr. Innov. 2016, 16, 307-322. [CrossRef]

95. Albattah, M.; Goodrum, P.; Taylor, T. The Influence of Demographics on Construction Workforce Shortages in the U.S. and Canada. In Proceedings of the International Construction Specialty Conference of the Canadian Society for Civil Engineering (ICSC), Vancouver, BC, Canada, 8-10 June 2015.

96. Baxter, K. Qatar's World Cup labour pains. Meed Middle East Econ. Dig. 2014, 58, 34.

97. Hidayat, B.; Novitasari, L.; Ophiyandri, T. Study of the skills of construction labours in building construction projects in Padang City. MATEC Web Conf. 2019, 276, 02013. [CrossRef]

98. Ramanigopal, C.S.; Mani, A.; Vasudevan, S.; Kumar, S.U. A comprehensive study of the human resource practices of the construction sector in tamil nadu. Clear Int. J. Res. Commer. Manag. 2018, 9, 1-8.

99. Griffin, J. Immigrants play key role in utility construction workforce. Undergr. Constr. 2009, 64, 42. Available online: https:/ucononline.com/magazine/2009/march-2009-vol-64-no-3/features/workforce-immigrantsplay-key-role-in-utility-construction (accessed on 1 July 2020).

100. Patricia, C. The Effect of Low-Skilled Immigration on U.S. Prices: Evidence from CPI Data. J. Political Econ. 2008, 116, 381. [CrossRef]

101. Bratsberg, B.; Raaum, O. Immigration and Wages: Evidence from Construction. Econ. J. 2012, 122, 1177-1205. [CrossRef]

102. Lai, Y.W.; Narayanan, S. The causes and consequences of immigrant labour in the construction sector in Malaysia. Int. Migr. 2005, 43, 31-57. [CrossRef]

103. Ling, F.Y.Y.; Dulaimi, M.F.; Chua, M. Strategies for Managing Migrant Construction Workers from China, India, and the Philippines. J. Prof. Issues Eng. Educ. Pract. 2013, 139, 19-26. [CrossRef] 
104. Number of Foreign construction Workers Employed in Singapore from 2013 to 2019. Available online: https://www.statista.com/statistics/1054354/singapore-foreign-construction-workers-employed/ (accessed on 1 July 2020).

105. Iskander, N.; Lowe, N. Building job quality from the inside-out: Mexican immigrants, skills, and jobs in the construction industry. Ind. Labor Relat. Rev. 2013, 66, 785-807. [CrossRef]

106. Golden, S.K.; Skibniewski, M.J. Immigration and Construction: Analysis of the Impact of Immigration on Construction Project Costs. J. Manag. Eng. 2010, 26, 189-195. [CrossRef]

107. Underwood, E. Unhealthy Work: Why Migrants Are Especially Vulnerable to Injury and Death on the Job. Available online: https://www.knowablemagazine.org/article/society/2018/unhealthy-work-why-migrantsare-especially-vulnerable-injury-and-death-job (accessed on 1 July 2020).

108. Mathur, R. 3D Printing in Architecture. Int. J. Innov. Sci. Eng. Technol. 2016, 3, 583-591.

109. Kirkpatrick, K. The Construction Industry in the 21st Century. Commun. ACM 2018, 61, 18-20. [CrossRef]

110. Boudreau, T. Technology breakthroughs: Helping the construction industry build smarter. Risk Manag 2016, 63. Available online: https://search.proquest.com/docview/2335133012?pq-origsite=gscholar\&fromopenview=true (accessed on 1 July 2020).

111. Aitbayeva, D.; Hossain, M.A. Building Information Model (BIM) Implementation in Perspective of Kazakhstan: Opportunities and Barriers. J. Eng. Res. Rep. 2020, 14, 13-24. [CrossRef]

Publisher's Note: MDPI stays neutral with regard to jurisdictional claims in published maps and institutional affiliations. 